\title{
Predictors of opinions on prison smoking bans: Analyses of survey data from Scottish staff and prisoners
}

\author{
Helen Sweeting', Sean Semple², Evangelia Demou' ${ }^{1}$ Ashley Brown ${ }^{2}$, Kate Hunt ${ }^{2}$
}

\begin{abstract}
INTRODUCTION Policy-makers and practitioners need to understand characteristics associated with support for smoking restrictions to identify both potential allies and groups requiring particular support/targeted communication in the face of restrictions. Using data from prison staff and prisoners, we explored the structure and correlates of opinions relating to prison smoking bans.

METHODS Questionnaires were completed by staff (online, N=1271; 27\% return) and prisoners (paper-based, $\mathrm{N}=2512 ; 34 \%$ ) in all 15 Scottish prisons in 201617. At that time, prisoners could smoke in their own cells and during outdoor recreation; staff smoking was prohibited anywhere on prison grounds. Staff and prisoner questionnaires included identical/very similar questions about opinions on smoking in prisons and prison smoking bans, own smoking behaviour, health and sociodemographic details. We also measured in every prison fine particulate matter $\left(\mathrm{PM}_{2.5}\right)$ as a proxy for secondhand smoke (SHS) levels.

RESULTS Principal components analysis identified two factors: 'Positive about bans' (higher scores among staff) and 'Bans will be difficult' (higher scores among prisoners). In multivariable analyses, 'Positive about bans' was associated with: not smoking (both staff and prisoners), better general health, more respiratory symptoms and working in an operational role among staff; and no asthma, more sensory symptoms, higher educational level and status/release date among prisoners. 'Bans will be difficult' was associated with: fewer sensory symptoms and lower prison SHS levels among staff and being a smoker among prisoners. In smoker-only analyses, heavier smokers were less positive about bans and more likely to believe bans will be difficult.

CONCLUSIONS Results suggest it is possible to be positive about prison smoking bans whilst also recognising and/or concerned about potential operational difficulties, and that these opinions are associated with several characteristics additional to smoker status. Support for future prison bans may be stronger if staff have access to objective SHS exposure measures.
\end{abstract}

\section{INTRODUCTION}

Breathing in secondhand tobacco smoke (SHS) harms health, with SHS exposure estimated as causing around $1 \%$ of total worldwide mortality ${ }^{1}$. Restrictions to SHS exposure, which are most successfully achieved via smoke-free legislation, have clear health benefits $^{2}$. Support for smoke-free policy is key to

\section{AFFILIATION \\ $1 \mathrm{MRC} / \mathrm{CSO}$ Social and \\ Public Health Sciences \\ Unit, University of Glasgow, \\ Glasgow, United Kingdom \\ 2 Institute for Social \\ Marketing, University of \\ Stirling, Stirling, United \\ Kingdom}

CORRESPONDENCE TO

Helen Sweeting. MRC/CSO

Social and Public Health

Sciences Unit, University of

Glasgow, Glasgow, United

Kingdom. E-mail: helen.

sweeting@glasgow.ac.uk

ORCID ID: https://orcid.

org/0000-0002-3321-5732

\section{KEYWORDS}

smoking restrictions, opinions, secondhand smoke, prisons, policy

Received: 4 March 2019 Revised: 25 April 2019

Accepted: 22 May 2019 successful implementation ${ }^{3,4}$. It is therefore important to identify not only levels of support among those subject to smoking restrictions, but also characteristics associated with different levels of support, since these might enable those involved in implementation/ enforcement to identify potential allies ${ }^{5,6}$ and better target measures to address expressed concerns and 
reduce potential problems.

Smoking restrictions have been increasingly introduced in public places since the 1970s, although with variation among jurisdictions in coverage. In many countries that have introduced workplace restrictions, exemptions occur for workplaces such as prisons, which are also regarded as 'homes'. In the absence of smoke-free policies, prisoner smoking rates are typically high, around 2-8 times those of the general population in studies internationally ${ }^{7}$. The health implications for prisoners who smoke and those (staff/prisoners) exposed to SHS have contributed to the introduction of increased restrictions or, in some jurisdictions, complete smoking bans in prisons ${ }^{7}$. We have previously documented Scottish prison staff and prisoner opinions on prison smoking bans, using survey and focus group data collected several months before the announcement that Scottish prisons would become smoke-free from November $2018^{8}$. This companion paper, based on survey data only, examines correlates of those opinions.

Surveys of both general populations and those in specific settings almost all find stronger support for hypothetical, proposed or currently implemented smoking restrictions among non-smokers. Examples within the general population include studies conducted in Australia ${ }^{9}$, Europe ${ }^{10}$, and Jordan ${ }^{11}$. Research within specific populations and/or settings also showing greater support for smoking restrictions among non-smokers is similarly international, including for example: Australian university staff and students $^{3}$, Dutch psychiatric hospital staff ${ }^{12}$, and UK bar workers ${ }^{13}$.

Some studies have also identified other characteristics associated with greater support of smoking restrictions. These include older age ${ }^{9,11,12}$, being female ${ }^{9}$, and higher socioeconomic status ${ }^{9}$. Greater support of restrictions has also been found among those with more knowledge of, or stronger beliefs about, harms associated with smoking and SHS exposure ${ }^{10,11}$. Finally, although one study found little difference in levels of support according to self-rated health ${ }^{10}$, others have found greater support among those reporting that SHS irritates their eyes, that they dislike its smell and that increased restrictions would reduce SHS 'annoyance" ${ }^{12}$.

Some population-based or workplace-based studies have focused specifically on smokers. These have found more positive opinions about smoking restrictions and, variously, lower nicotine dependence, lighter smoking, fewer perceived smoking-related personal benefits, lower smoker identity, and greater intention to quit ${ }^{5,6,9,14,15}$.

Very few surveys have been conducted on opinions about smoking restrictions in prisons; also potentially relevant are surveys in secure hospitals. An Irish study surveyed 90 prison staff among those from other workplaces, reporting agreement with: 'Should there be a smoking ban in prisons?' ( $41 \%$ yes); prohibition of smoking in enclosed areas ( $79 \%$ agreed); and whether a complete ban would 'create more problems in the prison' $(88 \% \text { yes })^{16}$. As with population or other workplace-based studies, this study found greater support for restrictions among non-smokers. Greater support for smoking restrictions among non-smokers has also been found among Vermont prison staff (when there was a ban on indoor smoking among both staff and prisoners) ${ }^{17}$; German prisoners (when smoking was allowed in cells $)^{18}$; Australian high security mental health inpatient facility $\operatorname{staff}^{19}$; and UK forensic unit in-patients ${ }^{20}$. The Vermont study also found that support for smoking restrictions on prisoners was stronger among prison staff than among prisoners, and uniformed staff (likely to have more contact with prisoners) were more supportive of continuing to permit prisoners to smoke outdoors than non-uniformed staff ${ }^{17}$. Surveys in a US secure psychiatric unit before and after a total ban also found that at both time-points, staff were more likely than patients to support the ban ${ }^{21}$.

\section{Aims}

This paper, based on survey data from Scottish prison staff and prisoners, aimed to explore:

- the structure of opinions with respect to prison smoking bans (specifically whether factor analysis of several statements about prison smoking bans identified more than one dimension);

- correlates of that/those dimension(s).

\section{METHODS}

\section{Study design}

Data are drawn from the Tobacco In Prisons study (TIPs), which is designed to evaluate the process of implementing enhanced tobacco control in Scottish prisons $^{8,22}$. TIPs is a three-phase study. Phase 1 was conducted before any announcements about smoking 
policy changes; Phase 2 following the announcement, but before introduction of a smoke-free policy; and Phase 3 following policy implementation. These Phase 1 survey data were collected in late 2016/early 2017, several months before the (July 2017) announcement that all Scottish prisons would become completely smoke-free from 30 November 2018. The Scottish prison estate consists of 13 publicly and two privately managed prisons. Most hold a mix of offender types and include: 10 accommodating males only, one with females only and four with both males and females, one accommodating male young offenders (aged 16-21 years), and one open prison accommodating low-supervision adult male offenders. At the time of data collection, prisoners were allowed to smoke in their own cells and during outdoor recreation; staff and visitors were prohibited from smoking anywhere on prison grounds.

An online prison staff survey was conducted, open 1 November to 16 December 2016. The survey link and reminders were circulated to our staff contacts in all 15 Scottish prisons, with requests to forward these to other prison (but not NHS/visiting) staff. The prisoner survey was conducted via paper questionnaires between November 2016 and April 2017. In two prisons, TIPs staff were escorted around residential areas, distributed questionnaires to all prisoners who said they were willing to complete one, answered queries and helped with completion if necessary. In a third (the open prison), TIPs staff distributed questionnaires during an evening meal. In the remaining 12 prisons, questionnaires were supplied for prison staff to distribute to every prisoner and collect (in sealed envelopes protecting confidentiality), generally during an overnight lock-up. Staff and prisoner questionnaires included identical or very similar questions around opinions on smoking in prisons and prison smoking bans, own smoking, health and sociodemographic details.

\section{Participants}

Questionnaires were completed by 1271 staff (27\%) and 2512 prisoners (34\%). Response/return rates varied considerably among prisons: $10-38 \%$ for staff, and $10-60 \%$ for prisoners. The staff sample was identical with respect to proportions of males (71\%) and females $(29 \%)$, and very similar with respect to age, for Scottish Prison Service staff in post as at 31 March $2017^{23}$. The prisoner sample included a slightly higher proportion of females (7\%) than within the Scottish prison population overall $(5 \%)^{23}$, and prisoner smoking rates $(74 \%)$ were slightly higher than those reported in the 2015 (72\%) and 2017 (68\%) Scottish prisoner surveys ${ }^{24}$.

\section{Measures}

Table 1 shows question wordings and analytic categories (if appropriate) for all variables.

Table 1. Dependent and independent variables - exact question wording and analytic categories (if appropriate)

\begin{tabular}{|c|c|}
\hline $\begin{array}{l}\text { Dependent } \\
\text { variables }\end{array}$ & Question wording \\
\hline $\begin{array}{l}\text { Smoking } \\
\text { ban opinion } \\
\text { items }\end{array}$ & $\begin{array}{l}\text { You have probably heard that smoking is no longer allowed in any areas (inside and outside) in } \\
\text { prisons in some countries around the world, like Canada, New Zealand and Wales. What do yo } \\
\text { think of prison smoking bans like these? (strongly agree, agree, no opinion, disagree, strongly } \\
\text { disagree for all) } \\
\text { - Prison smoking bans are a good idea } \\
\text { - Prison smoking bans cause a lot of trouble (e.g. prisoner fights, rioting, tobacco smuggling) } \\
\text { - Prison smoking bans help prisoners stop smoking long-term (and after release) } \\
\text { - Prison smoking bans are hard to enforce } \\
\text { - Most staff want prison smoking bans } \\
\text { - Prison smoking bans are OK if enough stop smoking support is available to prisoners } \\
\text { - Prison smoking bans are OK if prisoners are allowed e-cigarettes or vapes }\end{array}$ \\
\hline
\end{tabular}

In favour of Would you be in favour of increased smoking restrictions in Scottish prisons? (Yes - I would be increased in favour of increased smoking restrictions; I would have no opinion about increased smoking smoking restrictions; No - I would be against increased smoking restrictions)

restrictions 
Table 1. Continued

\begin{tabular}{|c|c|c|}
\hline $\begin{array}{l}\text { Inependent } \\
\text { variables }\end{array}$ & Question wording & Analytic categories \\
\hline \multicolumn{3}{|l|}{ AMONG ALL } \\
\hline Sex & Are you male or female? & $\begin{array}{l}\text { - Male } \\
\text { - Female }\end{array}$ \\
\hline Age (years) & $\begin{array}{l}\text { STAFF - How old are you? } \\
\text { PRISONERS - What is your age? }\end{array}$ & 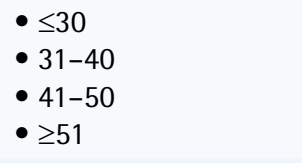 \\
\hline $\begin{array}{l}\text { Current } \\
\text { smoker }\end{array}$ & $\begin{array}{l}\text { STAFF - If yes to 'Have you ever smoked a cigarette?': } \\
\text { Do you smoke cigarettes nowadays? (yes/no) } \\
\text { PRISONERS - If yes to 'Have you ever smoked a cigarette?': } \\
\text { Do you smoke cigarettes now (in prison)? (yes/no) }\end{array}$ & $\begin{array}{l}\text { - Yes } \\
\text { - No }\end{array}$ \\
\hline $\begin{array}{l}\text { General } \\
\text { health }\end{array}$ & $\begin{array}{l}\text { How is your health in general? } \\
\text { (very good, good, fair, bad, very bad) }\end{array}$ & $\begin{array}{l}\text { - Very good } \\
\text { - Good } \\
\text { - Fair, bad or very bad }\end{array}$ \\
\hline $\begin{array}{l}\text { Diagnosed } \\
\text { asthma }\end{array}$ & Has a doctor ever told you that you have asthma? (yes/no) & $\begin{array}{l}\text { - Yes } \\
\text { - No }\end{array}$ \\
\hline $\begin{array}{l}\text { Respiratory } \\
\text { symptoms }\end{array}$ & $\begin{array}{l}\text { In the past } 4 \text { weeks have you: (yes/no, to each) } \\
\text { - Had a cold? } \\
\text { - Had wheezing or whistling in your chest? } \\
\text { - Felt short of breath? } \\
\text { - Usually coughed first thing in the morning? } \\
\text { - Coughed at all during the rest of the day or night? } \\
\text { - Brought up any phlegm? }\end{array}$ & $\begin{array}{l}- \text { None } \\
\text { - } 1-2 \\
\text { - } 3-6\end{array}$ \\
\hline $\begin{array}{l}\text { Sensory } \\
\text { symptoms }\end{array}$ & $\begin{array}{l}\text { In the past } 4 \text { weeks have: (yes/no, to each) } \\
\text { - Your eyes been red or irritated? } \\
\text { - You had a runny nose, sneezing or nose irritation? } \\
\text { - You had a sore or scratchy throat? }\end{array}$ & $\begin{array}{l}- \text { None } \\
\text { - } 1-2 \\
\text { - } 3\end{array}$ \\
\hline $\begin{array}{l}\text { Anxiety or } \\
\text { depression } \\
(\text { EQ5D5L) }\end{array}$ & $\begin{array}{l}\text { Please click (STAFF) / tick (PRISONERS) the box that best describes your health today: anxiety/ } \\
\text { depression } \\
\text { (I am not anxious or depressed, I am slightly anxious or depressed, I am moderately anxious or } \\
\text { depressed, I am severely anxious or depressed, I am extremely anxious or depressed) }\end{array}$ & $\begin{array}{l}\text { - None } \\
\text { - Slight } \\
\text { - Moderate, severe or } \\
\text { extreme }\end{array}$ \\
\hline $\begin{array}{l}\text { Prison SHS } \\
\left(\mathrm{PM}_{2.5}\right. \\
\text { outdoor } \\
\text { adjusted })\end{array}$ & $\begin{array}{l}\text { Area measurement of fine Particulate Matter }\left(\mathrm{PM}_{2.5}\right) \text { concentrations }\left(\mu \mathrm{g} / \mathrm{m}^{3}\right) \text { over a } 6 \text {-day period } \\
\text { within a hall or landing area in each prison using Dylos DC1700 monitors }{ }^{22} .\end{array}$ & $\begin{array}{l}\text { - Low } \\
\text { (<10, four prisons) } \\
\text { - Mid } \\
\text { (10-39, seven prisons) } \\
\text { - High } \\
\text { (>39, four prisons) }\end{array}$ \\
\hline \multicolumn{3}{|l|}{$\begin{array}{l}\text { AMONG } \\
\text { STAFF ONLY }\end{array}$} \\
\hline $\begin{array}{l}\text { Highest } \\
\text { educational } \\
\text { level }\end{array}$ & What was the highest level of education you received? (school, FE college, university) & $\begin{array}{l}\text { - School } \\
\text { - Further education } \\
\text { - Higher education }\end{array}$ \\
\hline Staff role & Is your role operational or non-operational? & $\begin{array}{l}\text { - Operational } \\
\text { - Non-operational }\end{array}$ \\
\hline Staff band & $\begin{array}{l}\text { What is your band? (Scottish Prison Service Band B; privately run prisons Administrative / } \\
\text { Scottish Prison Service Bands C+D; privately run prisons Prison Officer /Physical Education } \\
\text { Instructor /Scottish Prison Service Bands E+F; privately run prisons First line /Middle manager / } \\
\text { Scottish Prison Service Band G; privately run prisons Head of Function /Governor /Director) }\end{array}$ & $\begin{array}{l}\text { - SPS B-D (Admin, } \\
\text { prison officer, Phys. Ed) } \\
\text { - SPS E-G (Manager, } \\
\text { head of function, } \\
\text { governor) }\end{array}$ \\
\hline $\begin{array}{l}\text { Staff years } \\
\text { worked in } \\
\text { prisons }\end{array}$ & Altogether, how many years have you worked in prisons in total? & $\begin{array}{l}\bullet 0-1 \\
\bullet 2-4 \\
\bullet 5-9 \\
\bullet \geq 10\end{array}$ \\
\hline
\end{tabular}


Table 1. Continued

\begin{tabular}{|c|c|}
\hline $\begin{array}{l}\text { Inependent } \\
\text { variables }\end{array}$ & Question wording \\
\hline $\begin{array}{l}\text { AMONG } \\
\text { PRISONERS } \\
\text { ONLY }\end{array}$ & \\
\hline $\begin{array}{l}\text { Age left } \\
\text { education }\end{array}$ & How old were you when you left full-time education? \\
\hline $\begin{array}{l}\text { Prisoner } \\
\text { status }\end{array}$ & $\begin{array}{l}\text { Are you convicted or on remand? (yes/no) } \\
\text { If you are convicted, how long is your present sentence? } \\
\text { (up to } 90 \text { days, 3-12 months, } 1-4 \text { years, } 5-10 \text { years, over } 10 \text { years, life) }\end{array}$ \\
\hline
\end{tabular}

AMONG

SMOKERS

ONLY

Cigarettes

per day

STAFF - About how many cigarettes do you usually smoke on work days? About how many cigarettes do you usually smoke on your days off? (Daily calculated as average on a workday and days off; overall average calculated as [workday $\times 5+$ days off $\times 2] / 7$ )

PRISONERS - How many cigarettes (including roll-ups) do you usually smoke each day?

Craved cigarettes today

How much have you craved cigarettes today?

(not at all, hardly at all, a little, somewhat, quite a bit, a great deal)

Quit attempt STAFF - In the last year have you tried any of these things to help you stop smoking? (yes/no, (in prison) in to each) past year

- Attending an NHS stop smoking programme

- Using electronic cigarettes

- Using NRT (patches, gum or inhaler)

- Using prescribed Champix/Varenecline or Zyban/Buproprion

PRISONERS - have you tried anything to help you give up smoking in the past year? (yes/no, to each)

- Tried to get a place on a prison stop smoking programme

- Went to a group stop smoking programme

- Went to a one-to-one stop smoking programme

- Used nicotine replacement (e.g. patches, inhaler)

- Taken prescribed medicine (Champix, Zyban)

\section{Dependent variables}

Prison smoking ban opinion items ${ }^{9}$ were adapted from surveys of US prison staff opinions about restrictions to smoking in prisons ${ }^{17}$ and Scottish bar workers' attitudes to smoke-free public places legislation ${ }^{13}$. They comprised seven items on whether prison smoking bans: 1) are a good idea, 2) cause a lot of trouble, 3) stop prisoners smoking long-term, 4) are hard to enforce, 5) are $\mathrm{OK}$ if stop smoking support available, 6) are OK if e-cigarettes available, and 7) are wanted by most staff; with five answer options and a single item on agreement with increased smoking restrictions in Scottish prisons.

\section{Independent variables}

Staff and prisoners were asked about their age, sex and education. The questionnaires also asked about: staff role, seniority band and number of years they had worked in prisons, and prisoner status (unconvicted, convicted and time to release).

All participants were asked their current smoking status. Smokers were asked about daily cigarettes 
smoked, how much they had craved cigarettes today ${ }^{25}$, and whether they had tried a number of quit-smoking strategies in the past year.

All were asked health-related questions. These included health in general using a standard UK survey item $^{26}$ : 'has a doctor ever told you that you have asthma?'; and self-reported past month respiratory (wheezing/whistling, shortness of breath, morning cough, other cough, phlegm) and sensory symptoms (red/irritated eyes, runny nose/sneezing, sore/ scratchy throat). The symptom questions were based on International Union Against Tuberculosis and Lung Disease items previously included in studies of bar workers' health following smoke-free legislation ${ }^{27}$. The questionnaires also included the EQ-5D-5L, a standardised measure of health status including an item on current anxiety/depression ${ }^{28}$.

Between September 2016 and January 2017, TIPs also measured staff and prisoner SHS exposure in all Scottish prisons using multiple methods, including 6-day area measurement of fine Particulate Matter $(\mathrm{PM} 2.5)^{22}$.

\section{Ethics}

TIPs was approved by the Scottish Prison Service Research Access and Ethics Committee and University of Glasgow's College of Social Sciences Ethics Committee (ref: 400150214 for staff and prisoner data).

\section{Analyses}

Factor analyses (principal components analysis, varimax rotation) were conducted on the eight prison smoking ban opinion items. Exploratory analyses found one ('Prison smoking bans are OK if prisoners are allowed e-cigarettes or vapes') loaded on different factors for staff and prisoners (Supplementary Table 1). Analyses excluding this item resulted in two identical factors for staff and prisoners that explained $16 \%$ more total variance than an analysis constrained to a single factor (Supplementary Table 2 ). Factor analysis was therefore conducted of the remaining seven items for the prisoner and staff groups combined. The two resulting opinion factors (described in Results) were saved and formed the dependent variables in analyses of association.

Staff-prisoner differences on the prison smoking bans opinion factors (F-tests) and all other (independent) variables (chi-squared tests) were examined. Bivariable analyses (F-tests) examined differences in the two opinion factors according to each independent variable, separately for staff and for prisoners. ANOVAs entering the independent variable and one representing staff versus prisoner tested for significant interactions, indicating different associations within staff versus prisoners. Multivariable analyses (SPSS general linear models) entered those independent variables identified via bivariable analyses as significantly related $(\mathrm{p}<0.05)$ to each opinion factor, separately for staff and for prisoners. Similar analyses were conducted, restricted to smokers, entering cigarettes per day, craving and past-year quit attempt.

We tested for clustering by introducing a random intercept for prison in two key analyses (models entering staff versus prisoner, and smoker versus non-smoker; Supplementary Table 3). This was nonsignificant, therefore all analyses were conducted via standard linear models. As staff and prisoner questionnaire return rates varied among prisons, simple weights were derived to adjust for this. The results of final multivariable analyses based on unweighted and weighted data (Supplementary Table 4) were virtually identical, so results of unweighted analyses are presented.

\section{RESULTS}

Table 2 shows how each opinion statement loaded on the two opinion factors, for staff, prisoners and both groups combined. The first factor ('Positive about bans', $45.8 \%$ variance explained) included five items loading 0.6 or greater (prison smoking bans: are a good idea, are OK if stop smoking support available, stop prisoners smoking long-term, are wanted by most staff, and in favour of increased smoking restrictions in Scottish prisons). The second factor ('Bans will be difficult', $22.4 \%$ variance explained) included two items loading 0.6 or greater (prison smoking bans: are hard to enforce, and cause a lot of trouble).

Supplementary Table 5 shows mean scores on the opinion factors and distributions on the independent variables. Staff scores were significantly $(p<0.001)$ higher than those of prisoners on 'Positive about bans' (mean factor scores 0.647 and -0.351 , respectively), but lower on 'Bans will be difficult' (mean scores -0.234 and 0.127 , respectively). There 
Table 2. Factor analyses of smoking ban items conducted for staff, prisoners, and both - rotated component matrices for each group, ordered as per 'staff and prisoners'

\begin{tabular}{|c|c|c|c|c|c|c|}
\hline & \multicolumn{2}{|c|}{ STAFF } & \multicolumn{2}{|c|}{ PRISONERS } & \multicolumn{2}{|c|}{ STAFF AND PRISONERS } \\
\hline & Posilive & Dirficult & Posilive & Dillicult & Posilive ${ }^{b}$ & Diflicull ${ }^{c}$ \\
\hline Prison smoking bans are a good idea & 0.823 & -0.307 & 0.834 & -0.297 & 0.857 & -0.292 \\
\hline $\begin{array}{l}\text { Would you be in favour of increased smoking } \\
\text { restrictions in Scottish prisons? }\end{array}$ & 0.800 & -0.170 & 0.795 & -0.255 & 0.833 & -0.231 \\
\hline $\begin{array}{l}\text { Prison smoking bans are } \mathrm{OK} \text { if enough stop } \\
\text { smoking support is available to prisoners }\end{array}$ & 0.750 & 0.197 & 0.789 & -0.069 & 0.803 & 0.006 \\
\hline $\begin{array}{l}\text { Prison smoking bans help prisoners stop } \\
\text { smoking long-term (and after release) }\end{array}$ & 0.684 & -0.318 & 0.773 & -0.172 & 0.784 & -0.221 \\
\hline Most prison staff want smoking bans & 0.730 & -0.341 & 0.570 & 0.214 & 0.639 & -0.093 \\
\hline Prison smoking bans are hard to enforce & -0.125 & 0.853 & 0.045 & 0.840 & -0.024 & 0.889 \\
\hline $\begin{array}{l}\text { Prison smoking bans cause trouble (e.g. } \\
\text { prisoner fights, rioting, tobacco smuggling) }\end{array}$ & -0.176 & 0.836 & -0.300 & 0.737 & -0.332 & 0.760 \\
\hline Per cent variance explained & 41.8 & 25.8 & 42.3 & 21.2 & 45.8 & 22.4 \\
\hline
\end{tabular}

a Item 'Prison smoking bans are OK if prisoners are allowed e-cigarettes or vapes' excluded as it loaded on 'Bans will be difficult' for staff and 'Positive about bans' for prisoners (Supplementary Table 1). b Saved factor 'Positive about bans': range $=-2.46$ to 2.07, mean $=0.0, S D=1.0$. c Saved factor 'Bans will be difficult': range $=-3.28$ to 1.65 , mean $=$ $0.0, \mathrm{SD}=1.0$

were also significant staff-prisoner differences on all independent variables measured across both groups. Prisoners were more likely to be male and younger. Prisoners were also much more likely than staff to be smokers (74.2\% vs 9.7\%) and, among smokers, prisoners were heavier smokers, reported more craving and were less likely to have made a past-year quit attempt. Prisoners were more likely to report doctor-diagnosed asthma, more respiratory symptoms, fewer sensory symptoms and much higher rates of anxiety/depression. While similar proportions of staff and prisoners worked/lived in one of the prisons with lower measured SHS levels, staff were more likely than prisoners to be in one with higher levels. Most staff respondents had school-leaving or further educational levels and worked in operational and non- managerial roles. Most prisoners had left education by the age of 16 years and were convicted with three months or (much) longer until release.

Table 3 shows non-smokers scored higher on the 'Positive about bans' factor among both staff and, particularly, prisoners. Among both, those reporting the best health, but also those reporting more sensory symptoms had higher 'Positive about bans' scores. Among staff, those reporting more respiratory symptoms were also more positive about prison smoking bans, while among prisoners, those reporting no asthma were more positive. Higher 'Positive about bans' scores were also seen for older prisoners and staff working in prisons with higher measured SHS; neither sex nor anxiety/depression were associated with 'Positive about bans' in either group. In staff-

Table 3. Positive about bans factor according to independent variables - bivariable associations for staff and for prisoners, and significance of staff-by-prisoner interaction

\begin{tabular}{|c|c|c|c|c|c|}
\hline & \multicolumn{2}{|c|}{ STAFF } & \multicolumn{2}{|c|}{ PRISONERS } & \multirow{2}{*}{$\begin{array}{l}\text { STAFF } \\
\text { PRISONER (sig) }\end{array}$} \\
\hline & Mean & F (sig) & Mean & F (sig) & \\
\hline \multicolumn{6}{|c|}{ AMONG ALL } \\
\hline \multicolumn{6}{|c|}{ Sex } \\
\hline Male & 0.665 & & -0.347 & & \\
\hline Female & 0.636 & $0.4(0.552)$ & -0.410 & $0.7(0.413)$ & $(0.712)$ \\
\hline \multicolumn{6}{|c|}{ Age (years) } \\
\hline$\leq 30$ & 0.702 & & -0.475 & & \\
\hline $31-40$ & 0.708 & & -0.375 & & \\
\hline $41-50$ & 0.633 & & -0.321 & & \\
\hline$\geq 51$ & 0.620 & $1.0(0.391)$ & -0.077 & $15.4(<0.001)$ & $(<0.001)$ \\
\hline
\end{tabular}


Table 3. Continued

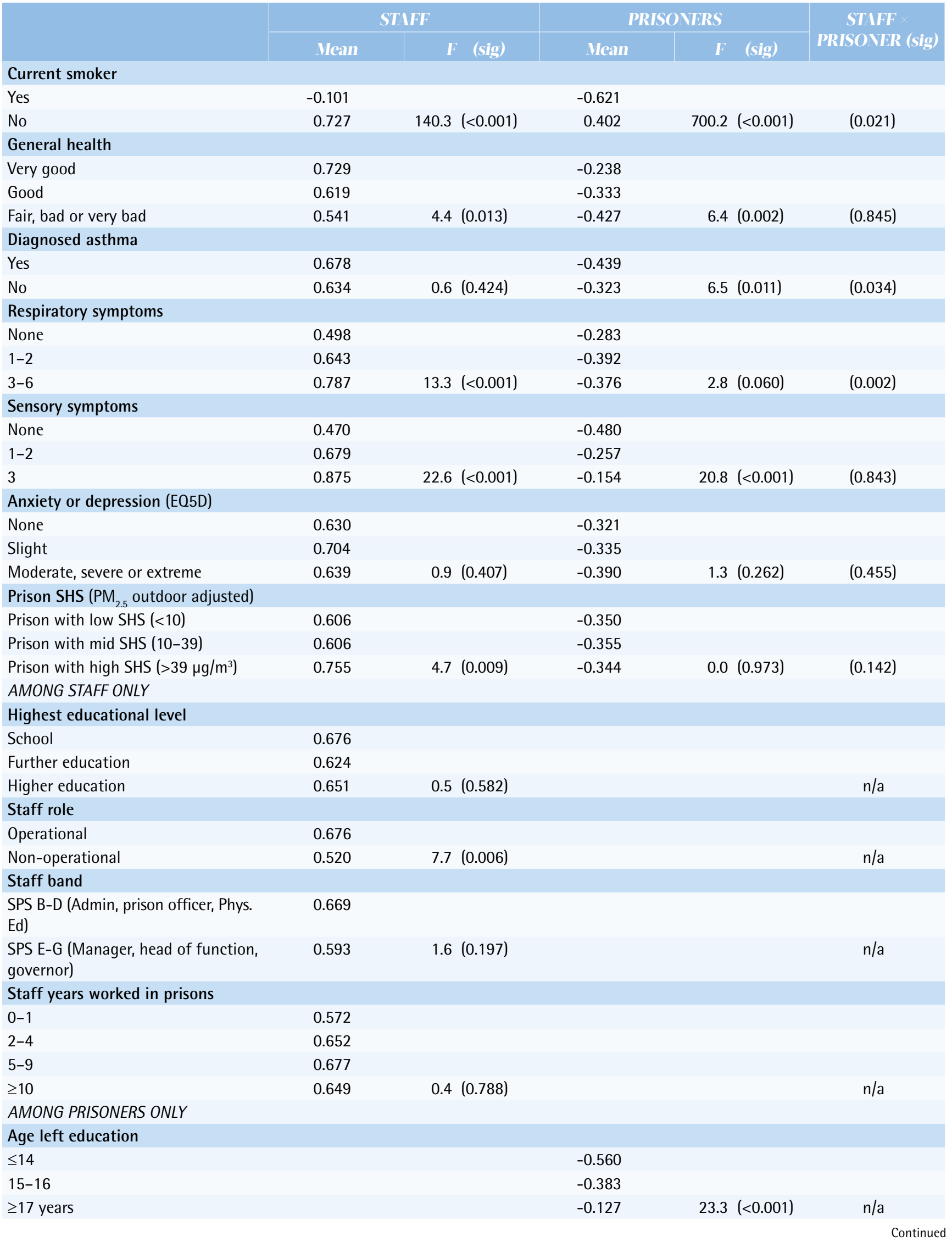


Table 3. Continued

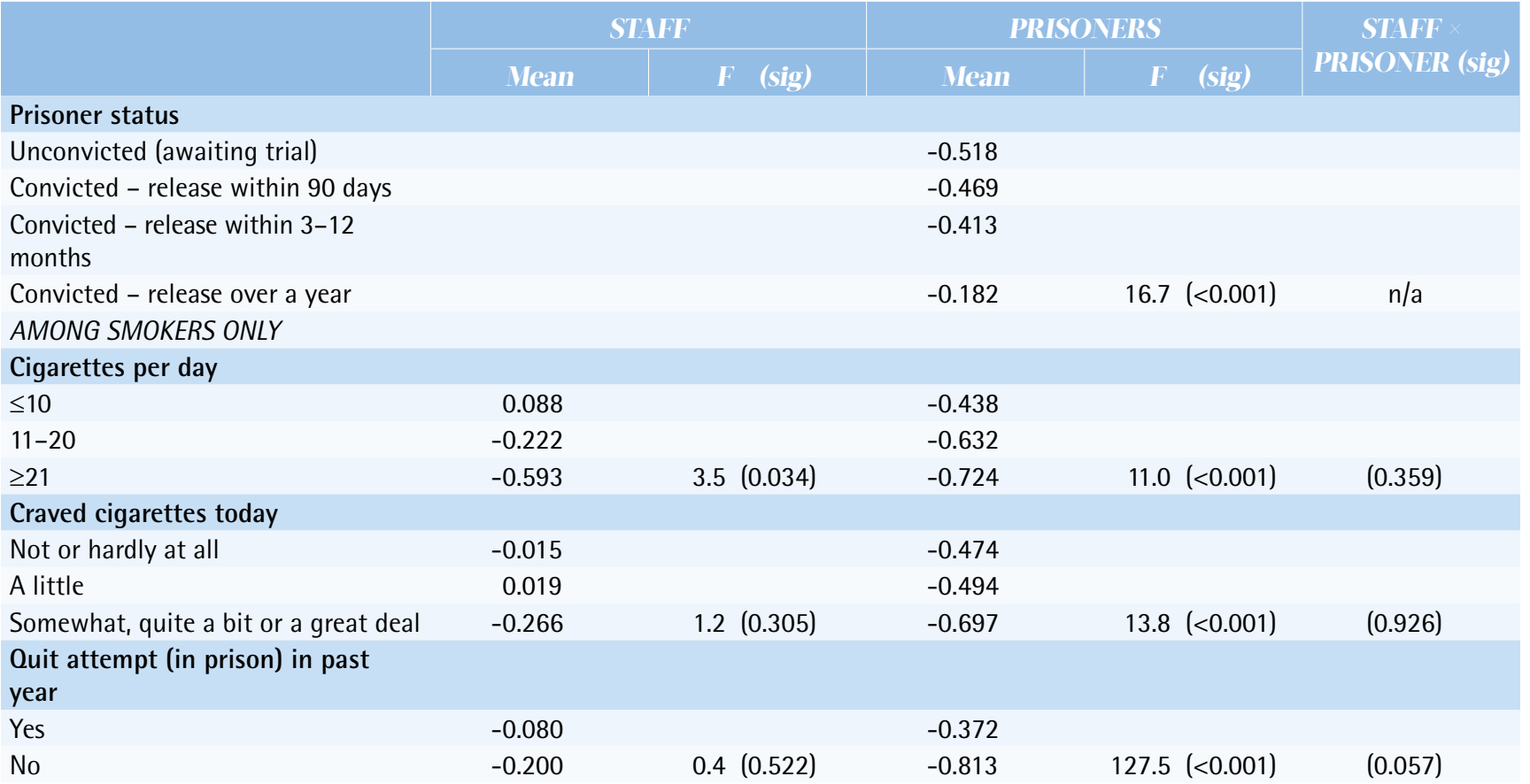

only analyses, those in operational roles had higher 'Positive about bans' scores. Among prisoners, those with more education and those with longer time until release were more positive, while unconvicted prisoners were least positive. Finally, among smokers only, those reporting lower cigarette consumption (both groups) and prisoners with fewer cravings and a past-year quit attempt were more positive about prison smoking bans.

Table 4 shows that among both groups, younger people and smokers had higher 'Bans will be difficult' factor scores. Among staff, those reporting worse health, but also those reporting no respiratory or sensory symptoms were more likely to believe bans will be difficult. Prisoners reporting greater anxiety/ depression and staff in prisons with lower measured SHS had higher scores on this factor. Higher 'Bans will be difficult' scores occurred among staff with least experience of working in prisons and prisoners with least education and those who were unconvicted. In smoker-only analyses, prisoners with greater cravings, but also those with a past-year quit attempt, had

Table 4. Bans will be difficult factor according to independent variables - bivariable associations for staff and for prisoners, and significance of staff-by-prisoner interaction

\begin{tabular}{|c|c|c|c|c|c|}
\hline & \multicolumn{2}{|c|}{ STAFF } & \multicolumn{2}{|c|}{ PRISONERS } & \multirow{2}{*}{$\begin{array}{l}\text { STAFF } \\
\text { PRISONER (sig) }\end{array}$} \\
\hline & Mean & F (sig) & Vean & F (sig) & \\
\hline \multicolumn{6}{|c|}{ AMONG ALL } \\
\hline \multicolumn{6}{|c|}{ Sex } \\
\hline Male & -0.266 & & 0.125 & & \\
\hline Female & -0.137 & $3.6(0.058)$ & 0.161 & $0.2(0.641)$ & $(0.364)$ \\
\hline \multicolumn{6}{|c|}{ Age (years) } \\
\hline$\leq 30$ & -0.027 & & 0.221 & & \\
\hline $31-40$ & -0.278 & & 0.131 & & \\
\hline $41-50$ & -0.304 & & 0.066 & & \\
\hline$\geq 51$ & -0.249 & $3.2(0.023)$ & 0.027 & $4.5(0.003)$ & $(0.370)$ \\
\hline \multicolumn{6}{|c|}{ Current smoker } \\
\hline Yes & 0.065 & & 0.218 & & \\
\hline No & -0.265 & $10.5(0.001)$ & -0.132 & $63.8(<0.001)$ & $(0.850)$ \\
\hline
\end{tabular}


Table 4. Continued

\begin{tabular}{|c|c|c|c|c|c|}
\hline & \multicolumn{2}{|c|}{ STAFF } & \multicolumn{2}{|c|}{ PRISONERS } & \multirow{2}{*}{$\begin{array}{l}\text { STAFF } \\
\text { PRISONER (sig) }\end{array}$} \\
\hline & Vean & F (sig) & Mean & F (sig) & \\
\hline \multicolumn{6}{|l|}{ AMONG ALL } \\
\hline \multicolumn{6}{|l|}{ General health } \\
\hline Very good & -0.334 & & 0.059 & & \\
\hline Good & -0.185 & & 0.144 & & \\
\hline Fair, bad or very bad & -0.158 & $3.0(0.049)$ & 0.146 & $1.5(0.215)$ & $(0.449)$ \\
\hline \multicolumn{6}{|l|}{ Diagnosed asthma } \\
\hline Yes & -0.336 & & 0.149 & & \\
\hline No & -0.212 & $2.7(0.101)$ & 0.129 & $0.2(0.664)$ & $(0.089)$ \\
\hline \multicolumn{6}{|l|}{ Respiratory symptoms } \\
\hline None & -0.160 & & 0.094 & & \\
\hline $1-2$ & -0.142 & & 0.150 & & \\
\hline $3-6$ & -0.359 & $4.9(0.008)$ & 0.155 & $1.0(0.379)$ & $(0.667)$ \\
\hline \multicolumn{6}{|l|}{ Sensory symptoms } \\
\hline None & -0.087 & & 0.131 & & \\
\hline $1-2$ & -0.224 & & 0.156 & & \\
\hline 3 & -0.537 & $13.7(<0.001)$ & 0.067 & $0.9(0.402)$ & $(0.029)$ \\
\hline \multicolumn{6}{|l|}{ Anxiety or depression (E05D) } \\
\hline None & -0.216 & & 0.040 & & \\
\hline Slight & -0.262 & & 0.098 & & \\
\hline Moderate, severe or extreme & -0.269 & $0.3(0.748)$ & 0.209 & $7.5(0.001)$ & $(0.059)$ \\
\hline \multicolumn{6}{|l|}{ Prison SHS ( PM $_{25}$ outdoor adjusted) } \\
\hline Prison with low SHS $(<10)$ & -0.108 & & 0.103 & & \\
\hline Prison with mid SHS (10-39) & -0.171 & & 0.161 & & \\
\hline Prison with high SHS (>39 $\left.\mu \mathrm{g} / \mathrm{m}^{3}\right)$ & -0.455 & $10.9(0.000)$ & 0.075 & $1.8(0.162)$ & $(0.003)$ \\
\hline \multicolumn{6}{|l|}{ AMONG STAFF ONLY } \\
\hline \multicolumn{6}{|l|}{ Highest educational level } \\
\hline School & -0.266 & & & & \\
\hline Further education & -0.192 & & & & \\
\hline Higher education & -0.249 & $0.6(0.539)$ & & & $\mathrm{n} / \mathrm{a}$ \\
\hline \multicolumn{6}{|l|}{ Staff role } \\
\hline Operational & -0.242 & & & & \\
\hline Non-operational & -0.198 & $0.3(0.576)$ & & & $\mathrm{n} / \mathrm{a}$ \\
\hline \multicolumn{6}{|l|}{ Staff band } \\
\hline $\begin{array}{l}\text { SPS B-D (Admin, prison officer, Phys. } \\
\text { Ed) }\end{array}$ & -0.259 & & & & \\
\hline $\begin{array}{l}\text { SPS E-G (Manager, head of function, } \\
\text { governor) }\end{array}$ & -0.154 & $1.6(0.199)$ & & & $\mathrm{n} / \mathrm{a}$ \\
\hline \multicolumn{6}{|l|}{ Staff years worked in prisons } \\
\hline $0-1$ & -0.066 & & & & \\
\hline $2-4$ & -0.150 & & & & \\
\hline $5-9$ & -0.114 & & & & \\
\hline$\geq 10$ & -0.303 & $2.9(0.033)$ & & & $\mathrm{n} / \mathrm{a}$ \\
\hline \multicolumn{6}{|l|}{ AMONG PRISONERS ONLY } \\
\hline \multicolumn{6}{|l|}{ Age left education } \\
\hline$\leq 14$ & & & 0.203 & & \\
\hline $15-16$ & & & 0.153 & & \\
\hline$\geq 17$ years & & & 0.032 & $4.2(0.015)$ & $\mathrm{n} / \mathrm{a}$ \\
\hline
\end{tabular}


Table 4. Continued

\begin{tabular}{|c|c|c|c|c|c|}
\hline & \multicolumn{2}{|c|}{ STAFF } & \multicolumn{2}{|c|}{ PRISONERS } & \multirow{2}{*}{$\begin{array}{l}\text { STAFF } \\
\text { PRISONEIR (sig) }\end{array}$} \\
\hline & Vean & F (sig) & Vean & F (sig) & \\
\hline \multicolumn{6}{|l|}{ AMONG PRISONERS ONLY } \\
\hline \multicolumn{6}{|l|}{ Prisoner status } \\
\hline Unconvicted (awaiting trial) & & & 0.247 & & \\
\hline Convicted - release within 90 days & & & 0.073 & & \\
\hline $\begin{array}{l}\text { Convicted - release within 3-12 } \\
\text { months }\end{array}$ & & & 0.146 & & \\
\hline Convicted - release over a year & & & 0.103 & $2.8(0.040)$ & $\mathrm{n} / \mathrm{a}$ \\
\hline \multicolumn{6}{|l|}{ AMONG SMOKERS ONLY } \\
\hline \multicolumn{6}{|l|}{ Cigarettes per day } \\
\hline$\leq 10$ & 0.062 & & 0.122 & & \\
\hline $11-20$ & 0.185 & & 0.238 & & \\
\hline$\geq 21$ & -0.545 & $2.5(0.085)$ & 0.270 & $2.8(0.064)$ & $(0.035)$ \\
\hline \multicolumn{6}{|l|}{ Craved cigarettes today } \\
\hline Not or hardly at all & -0.136 & & 0.146 & & \\
\hline A little & 0.141 & & 0.118 & & \\
\hline Somewhat, quite a bit or a great deal & 0.198 & $1.5(0.237)$ & 0.283 & $6.4(0.002)$ & $(0.329)$ \\
\hline \multicolumn{6}{|l|}{$\begin{array}{l}\text { Quit attempt (in prison) in past } \\
\text { year }\end{array}$} \\
\hline Yes & 0.048 & & 0.268 & & \\
\hline No & 0.142 & $0.2(0.641)$ & 0.181 & $4.1(0.044)$ & (0.331) \\
\hline
\end{tabular}

higher 'Bans will be difficult' scores.

In multivariable analyses, 'Positive about bans' factor scores remained significantly associated with not smoking for both staff and prisoners; with better general health, more respiratory symptoms and working in an operational role among staff; and with no asthma, more sensory symptoms, higher educational level and status (unconvicted versus convicted and release date) among prisoners (Table $5)$. Variance explained was much higher with respect to prisoners, attributable to the very strong association between own smoking and 'Positive about bans'.

Fewer variables were independently associated with 'Bans will be difficult', and variance explained was much lower. This was particularly the case for prisoners, where only current smoking was significantly positively associated in the multivariable model. Among staff, fewer sensory symptoms and lower prison SHS levels, but not own smoking, were independently associated with 'Bans will be difficult'.

Finally, multivariable analyses restricted to prisoners who smoked (no equivalent analyses for staff since multiple variables were not significantly associated with either opinion factor among staff smokers) showed that all variables significant in bivariable analyses of association remained so in the multivariable analyses. Thus, among prisoners who smoked, cigarettes per day remained inversely associated with 'Positive about bans', and craved cigarettes and past-year quit attempt remained

Table 5. Bans factors according to independent variables - multivariable associations for staff and for prisoners

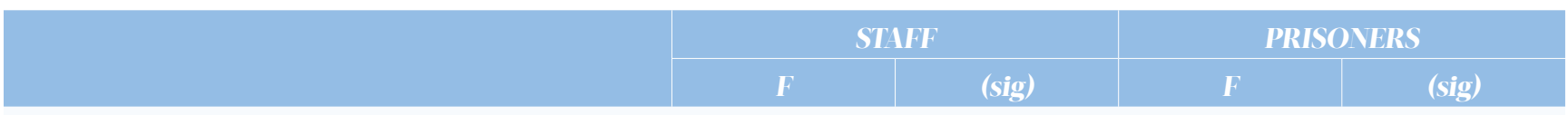

\section{AMONG ALL}

Positive about bans factor

Population: STAFF 1108, PRISONERS 2011

Age

Current smoker

General health

$\begin{array}{cccc}- & - & 0.7 & (0.578) \\ 120.7 & (<0.001) & 460.9 & (<0.001) \\ 5.4 & (0.005) & 0.0 & (0.977) \\ - & - & 4.5 & (0.033)\end{array}$

Diagnosed asthma 
Table 5. Continued

\begin{tabular}{|c|c|c|c|c|}
\hline & \multicolumn{2}{|c|}{ STAFF } & \multicolumn{2}{|c|}{ PRISONERS } \\
\hline & $F$ & (sig) & $F$ & (sig) \\
\hline \multicolumn{5}{|l|}{ AMONG ALL } \\
\hline \multicolumn{5}{|l|}{ Positive about bans factor } \\
\hline \multicolumn{5}{|l|}{ Population: STAFF 1108, PRISONERS 2011} \\
\hline Respiratory symptoms & 9.1 & $(<0.001)$ & - & - \\
\hline Sensory symptoms & 3.0 & $(0.051)$ & 25.2 & $(<0.001)$ \\
\hline Prison SHS ( $\mathrm{PM}_{2.5}$ outdoor adjusted) & 2.7 & $(0.065)$ & - & - \\
\hline Staff - role & 4.1 & $(0.044)$ & $\mathrm{n} / \mathrm{a}$ & \\
\hline Prisoner - age left education & $\mathrm{n} / \mathrm{a}$ & & 5.4 & $(0.004)$ \\
\hline Prisoner - unconvicted /convicted/release status & $\mathrm{n} / \mathrm{a}$ & & 4.8 & $(0.003)$ \\
\hline (Adjusted $R^{2}$ ) & $(0.148)$ & & $(0.254)$ & \\
\hline \multicolumn{5}{|l|}{ Bans will be difficult factor } \\
\hline \multicolumn{5}{|l|}{ Population: STAFF 1085, PRISONERS 2077} \\
\hline Age & 1.0 & $(0.386)$ & 2.0 & $(0.109)$ \\
\hline Current smoker & 3.4 & $(0.065)$ & 35.9 & $(<0.001)$ \\
\hline General health & 2.5 & $(0.085)$ & - & - \\
\hline Respiratory symptoms & 1.6 & $(0.203)$ & - & - \\
\hline Sensory symptoms & 6.3 & $(0.002)$ & - & - \\
\hline Anxiety or depression (E05D) & - & - & 2.5 & $(0.081)$ \\
\hline Prison SHS ( $\mathrm{PM}_{2.5}$ outdoor adjusted) & 5.8 & $(0.003)$ & - & - \\
\hline Staff - years worked in prisons & 0.5 & $(0.713)$ & $\mathrm{n} / \mathrm{a}$ & \\
\hline Prisoner - age left education & $\mathrm{n} / \mathrm{a}$ & & 1.2 & $(0.292)$ \\
\hline Prisoner - unconvicted /convicted /release status & $\mathrm{n} / \mathrm{a}$ & & 2.1 & $(0.100)$ \\
\hline (Adjusted $R^{2}$ ) & $(0.039)$ & & $(0.030)$ & \\
\hline \multicolumn{5}{|l|}{ AMONG SMOKERS ONLY } \\
\hline \multicolumn{5}{|l|}{ Positive about bans factor } \\
\hline \multicolumn{5}{|l|}{ Population: PRISONERS 1596} \\
\hline Cigarettes per day & - & - & 7.1 & $(0.001)$ \\
\hline Craved cigarettes today & - & - & 7.5 & $(0.001)$ \\
\hline Quit attempt (in prison) in past year & - & - & 132.4 & $(<0.001)$ \\
\hline (Adjusted R²) & & & $(0.094)$ & \\
\hline \multicolumn{5}{|l|}{ Bans will be difficult factor } \\
\hline \multicolumn{5}{|l|}{ Population: PRISONERS 1614} \\
\hline Craved cigarettes today & - & - & 8.4 & $(<0.001)$ \\
\hline Quit attempt (in prison) in past year & - & - & 4.4 & $(0.037)$ \\
\hline (Adjusted $\mathrm{R}^{2}$ ) & & & $(0.011)$ & \\
\hline
\end{tabular}

associated with both opinions factors.

Given staff versus prisoners and smoker versus non-smoker differences in scores on the two smoking ban opinion factors, additional analyses (not shown in Tables) were conducted to see if the much higher prisoner smoking rate could account for differences in staff and prisoner opinions. Whilst the differences decreased substantially after adjustment for smoking status, they remained significant: 'Bans are positive' according to staff/prisoner $\mathrm{F}=1050.6(\mathrm{p}<0.001)$ before, and $\mathrm{F}=110.8(\mathrm{p}<0.001)$ after adjustment for smoking status; whilst 'Bans will be difficult' according to staff/prisoner $\mathrm{F}=108.8(\mathrm{p}<0.001)$ before, and $\mathrm{F}=10.1 \quad(\mathrm{p}=0.002)$ after adjustment.

\section{DISCUSSION}

Analyses of survey responses from Scottish prison staff and prisoners on items eliciting opinions about 
prison smoking bans, collected before announcements about a smoke-free policy implementation date in all Scottish prisons, suggest opinions in both groups could be related to two underlying dimensions (factors). The first, accounting for most variance, represented 'positive' opinions towards prison smoking bans, and the second highlighted their potential difficulties. Importantly, this suggests it is possible to be both generally positive about prison smoking bans, whilst also recognising (and potentially concerned about) the operational difficulties they may bring. This was also evident in analyses of qualitative data from Scottish prison staff obtained around the same time that found 'Staff views were influenced by beliefs about: acceptability of the policy in principle and whether/how bans could be achieved's.

Consistent with almost every other study within both general ${ }^{9-11}$, and specific populations or setting $\mathrm{s}^{3,12,13}$, including prisons and forensic psychiatric units ${ }^{16-20}$, non-smokers were more likely to be positive about prison smoking bans. They were also less likely to suggest their introduction would bring difficulties. The effects of smoker status were particularly marked for prisoners, probably because staff were not allowed to smoke on prison premises at the time of the survey. This in turn would mean staff smokers, while potentially more sympathetic than non-smokers towards smoking prisoners, had little to lose from a smoking ban (and potentially gains in terms of their own health, reduced temptations to smoke and perceptions of unfairness from seeing prisoners smoking). Also consistent with studies of similar institutions ${ }^{17,21}$, staff were more positive about bans, and less likely to anticipate difficulties than prisoners. Many, but not all, of the staff and prisoner opinion differences were explained by prisoners' higher smoking rates.

Previous studies have identified a range of other characteristics associated with greater support for smoking bans (in a range of contexts), including: older age $^{9,11,12}$; being female ${ }^{9}$; having higher socioeconomic status ${ }^{9}$; dislike of, or symptoms associated with, $\mathrm{SHS}^{12}$; and, among smokers, variables relating to heaviness/ dependence and intention to quit ${ }^{5,6,9,14,15}$. Although our analyses did not find differences between the opinions of males and females, there were differences according to age (older prisoners more positive; younger staff and prisoners more likely to identify potential difficulties) and, among prisoners, educational level (those with least education were least positive and most likely to identify potential difficulties). Although there were no differences according to staff band (managerial/ non-managerial), those in operational roles (so more likely to have regular exposure to prisoners' SHS) were more positive about prison smoking bans, and those who had worked for less time in prisons (i.e. less experienced) were more likely to suggest bans would bring operational difficulties. Unconvicted prisoners were least positive about prison smoking bans and most likely to believe they would cause difficulties, while those with the longest time to release were most positive. Given that, in the absence of smoking bans, smoking is a strong part of prison culture ${ }^{29}$, this finding is perhaps unexpected, but may be because those who are unconvicted have little incentive to 'buy into' smoking restrictions and/or are concerned about measures further restricting their freedoms. Among staff, but not prisoners, those in prisons where our objective SHS measurements showed higher SHS exposure levels ${ }^{22}$, were more positive about bans and less likely to believe they would cause difficulties. Although staff completed the survey before our SHS results were available, those working in prisons where levels were higher may have inferred this from their own experience and knowledge of their prison's architecture and ventilation systems.

Few studies have examined associations between health and opinions about smoking restrictions. Among both staff and prisoners, those reporting better general health were more positive about a ban, while staff reporting better health were least likely to say bans will be difficult, and prisoners with no asthma were more positive. Those already in poor health may disregard 'additional' health harms or, perhaps, have a more negative outlook generally, including in respect to a ban. However, some of these differences disappeared in the multivariable analyses, suggesting that they were partially accounted for by (non)smoker status. Importantly, experience of sensory symptoms (red/irritated eyes, runny nose/ sneezing, sore/scratchy throat) associated with SHS exposure, remained significant in multivariable analyses, suggesting that they may play an important role in reminding people of ongoing exposure to a potential health hazard.

The results of analyses restricted to smokers 
were also largely consistent with previous studies of attitudes towards smoking restrictions in other populations that have found more positive opinions about smoking restrictions among lighter, less dependent and/or committed smokers ${ }^{5,6,9,14,15}$. They are also in line with evidence that more nicotine dependent prisoners are a group that might be more likely to try to continue smoking after a prison smoking ban $^{30}$. Heavier, more dependent smokers, without a recent quit attempt (potentially representing more committed smokers) were less positive about prison smoking bans. These associations were generally significant for prisoners, and in the same direction for staff, among whom numbers of smokers were relatively small. More dependent smokers and those reporting a recent quit attempt were also more likely to view bans as bringing operational difficulties. Although counter-intuitive, perhaps the latter group were reflecting on their own difficulties in quitting.

This study has both strengths and limitations. Strengths include its size and the fact that it encompasses both staff and prisoner views collected, for the first time, across all prisons within a country's criminal justice system. Another major strength is the fact that identification of two opinion dimensions in these quantitative analyses is consistent with the results of our analyses of independent qualitative data from prison staff on smoking bans in prisons. An important limitation is the relatively low response/ return rates and potentially unrepresentative samples. However, those included were very similar to all Scottish prison staff and prisoners with respect to characteristics on which comparable data are available. Another limitation is the cross-sectional nature of the self-report data, hence we cannot draw conclusions on causality, particularly on relationships between the health-related variables and opinions on prison smoking bans. Here, the relative lack of association between anxiety/depression and opinions provides some reassurance that the obtained associations were not simply the result of negative affectivity.

Previous studies have highlighted the importance of understanding characteristics associated with different levels of support for smoking restrictions as a way for policy-makers and practitioners to identify potential allies when introducing restriction $s^{5,6}$, and to identify groups who may need particular support or more targeted communication in the face of restrictions.
Our analyses suggest that although smoker status and, among smokers, dependency and smoker identity are significant, the presence of sensory symptoms related to SHS exposure and working in environments where people are more heavily exposed to SHS were determinants of levels of support for smoking restrictions. The latter is a key finding, suggesting that future prison (or other workplace) bans internationally might be more strongly supported by staff if objective measurements of SHS exposure are available; such measurements could be a routine first step in the process towards smoke-free prisons. Identification of two opinion dimensions in our analysis, with the suggestion that it is possible to be both generally positive about prison smoking bans and concerned about potential associated operational difficulties, also has practical implications. It indicates that those who raise concerns over practical issues about implementation/enforcement of prison smoking bans are not necessarily unsupportive of their introduction and, equally, those who express strong support for prison smoking bans may, nevertheless, have some apprehension over unintended negative consequences. While this may be particularly important in respect to prison smoking bans where the operational difficulties are potentially very significant, it suggests policy-makers and implementers need to acknowledge the legitimacy of both dimensions of opinion in their measures to address concerns and mitigate potential problems.

\section{CONCLUSIONS}

Policy-makers and practitioners need to identify potential allies and adopt appropriate communication strategies when introducing smoking restrictions. Those operating within prison services would benefit from recognising the complexity of staff and prisoner opinions about changes to smoking rules in their communication strategy, since those who appear generally positive about prison smoking bans may also be concerned about associated potential operational difficulties. Associations between opinions and characteristics, including both symptoms related to SHS exposure and measured SHS levels, suggest support for future smoking restrictions in prisons (or other workplaces) may be stronger if links with symptoms are highlighted and objective SHS exposure measures included in the communication strategy. 


\section{REFERENCES}

1. Öberg M, Jaakkola M, Woodward A, Peruga A, PrüssUstün A. Worldwide burden of disease from exposure to second-hand smoke: a retrospective analysis of data from 192 countries. The Lancet. 2011;377:139-146. doi:10.1016/s0140-6736(10)61388-8

2. Pell J, Haw S. The triumph of national smoke-free legislation. Heart. 2009;95:1377-1379. doi:10.1136/hrt.2009.176230

3. Burns S, Hart E, Jancey J, Hallett J, Crawford G, Portsmouth L. A cross sectional evaluation of a total smoking ban at a large Australian university. BMC Research Notes. 2016;9:288. doi:10.1186/s13104-016-2090-7

4. International Agency for Research on Cancer. Evaluating the effectiveness of smoke-free policies. Lyon, France: International Agency for Research on Cancer, WHO; 2009.

5. Lacchetti C, Cohen J, Ashley M, et al. Is nicotine dependence related to smokers' support for restrictions on smoking? Nicotine \& Tobacco Research. 2001;3:257260. doi:10.1080/14622200123996

6. Poland B, Cohen J, Ashley M, et al. Heterogeneity among smokers and non-smokers in attitudes and behaviour regarding smoking and smoking restrictions. Tobacco Control. 2000;9:364-371. doi:10.1136/tc.9.4.364

7. Spaulding A, Eldridge G, Chico C, et al. Smoking in Correctional Settings Worldwide: Prevalence, Bans, and Interventions. Epidemiologic Reviews. 2018;40:82-95. doi:10.1093/epirev/mxy005

8. Brown A, Sweeting H, Logan G, Demou E, Hunt K. Prison staff and prisoner views on a prison smoking ban: evidence from the Tobacco In Prisons study. Nicotine and Tobacco Research. 2018. doi:10.1093/ntr/nty092

9. McAllister I. Public opinion in Australia on restricting smoking in public places. Tobacco Control. 1995;4:30-35. doi:10.1136/tc.4.1.30

10. Reuband K. Tabakkonsum im gesellschaftlichen Wandel. Verbreitung des Konsums und Einstellung zu Rauchverboten, Düsseldorf 1997-2009 (Tobacco consumption in a changing society. Extent of consumption and attitudes to smoking bans, Dusseldorf 1997-2009). Gesundheitswesen. 2014;76:32-40. doi:10.1055/s-0033-1334953

11. Obeidat N, Ayub H, Bader R, et al. Public support for smokefree policies in Jordan, a high tobacco burden country with weak implementation of policies: status, opportunities and challenges. Global Public Health. 2016;11:1246-1258. doi :10.1080/17441692.2015.1065896

12. Willemsen M, Gorts C, Van Soelen P, Jonkers R, Hilberink S. Exposure to environmental tobacco smoke (ETS) and determinants of support for complete smoking bans in psychiatric settings. Tobacco Control. 2004;13:180-185. doi:10.1136/tc.2003.004804

13. Hilton S, Semple S, Miller B, et al. Expectations and changing attitudes of bar workers before and after the implementation of smoke-free legislation in Scotland. BMC Public Health. 2007;7:206. doi:10.1186/1471-2458-7-206

14. Meijer E, Gebhardt W, Dijkstra A, Willemsen M, Van Laar C. Quitting smoking: the importance of non-smoker identity in predicting smoking behaviour and responses to a smoking ban. Psychology and Health. 2015;30:13871409. doi:10.1080/08870446.2015.1049603

15. Zlatev M, Pahl S, White M. Perceived risk and benefit for self and others as predictors of smokers' attitudes towards smoking restrictions. Psychology and Health. 2010;25:167-182. doi:10.1080/08870440802372449

16. McGaffrey M, Goodman P, Gavigan A, et al. Should Any Workplace Be Exempt from Smoke-Free Law: The Irish Experience. Journal of Environmental and Public Health. 2012. doi:10.1155/2012/545483

17. Carpenter M, Hughes J, Solomon L, Powell T. Smoking in correctional facilities: a survey of employees. Tobacco Control. 2001;10:38-42. doi:10.1136/tc.10.1.38

18. Buth S, Stover H, Ritter C. Tabakprävention in Gefängnissen (Tobacco prevention in prisons: a survey among prisoners on tobacco use and the possibilities and obstacles regarding the reduction of smoking in prison). Suchttherapie. 2013;14:160-169. doi: $10.1055 / \mathrm{s}-0033-1348250$

19. Hehir AM, Indig D, Prosser S, Archer VA. Implementation of a smoke-free policy in a high secure mental health inpatient facility: staff survey to describe experience and attitudes. BMC Public Health. 2013;13:315. doi:10.1186/1471-2458-13-315

20. Dickens G, Stubbs J, Popham R, Haw C. Smoking in a forensic psychiatric service: a survey of inpatients' views. Journal of Psychiatric and Mental Health Nursing. 2005;12:672-678. doi:10.1111/j.1365-2850.2005.00892.x

21. Haller E, McNiel DE, Binder RL. Impact of a smoking ban on a locked psychiatric unit. Journal of Clinical Psychiatry. 1996;57:329-332.

22. Semple S, Sweeting H, Demou E, Logan G, O’Donnell R, Hunt K. Characterising the exposure of prison staff to second-hand tobacco smoke. Annals of Work Exposures and Health. 2017;61:809-821. doi:10.1093/annweh/wxx058

23. Scottish Prison Service. Scottish Prison Service Annual Report \& Accounts 2016-2017. Edinburgh: Scottish Prison Service; 2017.

24. Carnie J, Broderick R, Cameron J, Downie D, Williams G. Prisoner Survey 2017. Edinburgh: Scottish Prison Service; 2017.

25. West R, Usher M. Is the ten-item Questionnaire of Smoking Urges (QSU-brief) more sensitive to abstinence than shorter craving measures? Psychopharmacology. 2010;208:427-432. doi:10.1007/s00213-009-1742-x

26. Christie S, McLean J. The Scottish Health Survey 2016 edition. Edinburgh: Scottish Government; 2017.

27. Eisner M, Smith A, Blanc P. Bartenders' respiratory health after establishment of smoke-free bars and taverns. Journal of American Medical Assocation. 1998;280:1909- 
1914. doi:10.1001/jama.280.22.1909

28. The EuroQol Group. EuroQol-a new facility for the measurement of health-related quality of life. Health Policy. 1990;16:199-208. doi:10.1016/0168-8510(90)90421-9

29. Ritter C, Stöver H, Levy M, Etter JF, Elger B. Smoking in prisons: the need for effective and acceptable interventions. Journal of Public Health Policy. 2011;32:32-45. doi:10.1057/jphp.2010.47

30. Cropsey KL, Kristeller JL. The effects of a prison ban on smoking behavior and withdrawal symptoms. Addictive Behaviors. 2005;30:589-594. doi:10.1016/j.addbeh.2004.07.003

\section{ACKNOWLEDGEMENTS}

We are grateful to the staff and prisoners who completed the surveys and staff at the Scottish Prison Service and at the two non-SPSrun prisons (HMP Addiewell and HMP Kilmarnock) who assisted with the study, including the air quality measurements. We thank colleagues at MRC/CSO Social and Public Health Sciences Unit, Public Health Research Facility for help with data management and input (in particular D. Walker, K. Campbell and M. Tolan). We gratefully acknowledge the contribution of our TIPs co-investigators to the overall design of the study (L. Bauld, K. Boyd, P. Conaglen, P. Craig, D. Eadie, A. Leyland and J. Pell). We particularly thank S. Corbett, L. Dorward, R. Parker and members of the SPS Research Advisory Group for their helpful input during the design and conduct of this research.

\section{CONFLICTS OF INTEREST}

The authors declare that they have no competing interests, financial or otherwise, related to the current work. H. Sweeting is a member of the ASH Scotland Board and its Policy and Development Committee and chairs the Scottish Tobacco-free Alliance Research Group. The rest of the authors have also completed and submitted an ICMJE form for disclosure of potential conflicts of interest.

\section{FUNDING}

The TIPs study was funded by the National Institute for Health Research Public Health Research Programme (project number 15/55/44). The authors acknowledge funding from the Medical Research Council (MC_UU12017/12 and MC_PC_13027 to ED) and Chief Scientist Office (SPHSU12). The views and opinions expressed in this work are those of the authors and do not necessarily reflect those of the Public Health Programme, NIHR, NHS or the Department of Health.

\section{AUTHORS' CONTRIBUTIONS}

H.S., S.S. and E.D. are Co-Investigators and K.H. Principal Investigator of the Tobacco In Prisons study (TIPS) and therefore all contributed to the overall design, methods and materials of the study. H.S. and K.H. managed the staff and prisoner surveys and S.S. led on the secondhand smoke measurements. H.S. conceived and conducted the analyses presented here and first-drafted the paper. All authors contributed to subsequent drafts and approved submission.

PROVENANCE AND PEER REVIEW

Not commissioned; externally peer reviewed. 